\section{Geologic processes in sedimentary basins inferred from three-dimensional seismic imaging}

\author{
Richard J. Davies, 3DLab, School of Earth, Ocean and Planetary Sciences, Main \\ Building, Park Place, Cardiff University, Cardiff CF10 3YE, UK, richard.davies@earth. \\ cf.ac.uk; Henry W. Posamentier, Anadarko Canada Corporation, 425 1st Street SW, \\ Calgary, Alberta T2P4V4, Canada, Henry_Posamentier@anadarko.com
}

\begin{abstract}
Three-dimensional seismic reflection data are now being used to understand a range of fundamental geological processes. However, like most geological investigative tools, it is the products of geological processes that are revealed by these data rather than the processes themselves; processes inevitably need to be inferred. We outline how the interpretation of three-dimensional seismic data is undertaken in sedimentary basins and then describe selected examples of recent applications of these data with the objective of showing how sedimentary basin processes can be unraveled from seismic imagery. These examples cover the diverse disciplines of (1) geomorphology and process sedimentology, (2) diagenetic processes, (3) magma intrusion into the upper continental crust, and (4) fluid flow in sedimentary basins.
\end{abstract}

\section{INTRODUCTION}

As a byproduct of the search for hydrocarbons, the earth science community has advanced the frontiers of earth science through the development and refinement of the equivalent of the medical world's computed tomography (CAT) scan. Three-dimensional seismic reflection technology enables the geoscientist to image volumes of Earth's subsurface much in the same way CAT scans image the human body. These types of data have long been used in the hydrocarbon industry (e.g., Bally, 1987; Weimer and Davis, 1996; Brown, 1999; Davies et al., 2004) and increasingly in the past decade have been revealing the three-dimensional form of a host of new geological phenomena in sedimentary basins. Three-dimensional seismic reflection profiling is now shedding light on fundamental geologic processes that span a surprisingly wide range of earth science disciplines, from structural geology to geomorphology to fluid migration through strata within sedimentary basins.

Like its medical counterpart, threedimensional seismology is a form of remote sensing, a means of imaging the interior of a solid object in a noninvasive way. The transmission of seismic energy and the return of energy back to the surface by reflection and refraction allows for some of the fabric and texture of Earth to be imaged, digitally enhanced, and evaluated. The resultant images capture snapshots of the subsurface at a moment in time, and analysis of a series of images facilitates the reconstruction of the geological evolution of the subsurface. The scale of such analysis ranges from whole Earth (e.g., Grand et al., 1997) to the relatively shallow parts of the crust examined in this contribution.

Three-dimensional reflection seismology began to be developed in the 1970s. Rather than acquiring parallel seismic line data separated by kilometers, as was the norm with two-dimensional seismic acquisition, acoustic data from multiple closely spaced rectilinear lines were collected (at first every 100 $\mathrm{m}$, then every $50 \mathrm{~m}$, and now commonly every 25-12.5 m), providing regular, grid-like, data point spacing. These data pass through various operations during seismic processing (Yilmaz, 2001) that ultimately aim to increase the signal-to-noise ratio and resolution of the subsurface reflections. The result

\section{DATA AND INTERPRETATION}

is a three-dimensional cube of seismic reflections that can be interrogated using a wide range of interpretation software. Three-dimensional seismic coverage in mature hydrocarbon provinces can cover entire sedimentary basins, and global coverage is increasing as acquisition, processing, hardware, and software costs are decreasing. The sheer vertical and lateral extent of data coverage means that tens of meters to basin-scale phenomena can be analyzed.

The interpretation methodology is riddled with buzzwords, many of which are specific to the growing number of software products that can be employed to interpret and visualize these data. Seedpicking, autopicking, voxbodies, and reflection attributes are a few of the terms that have become part of the seismic interpreter's vocabulary (e.g., Brown, 1999). With specialized software, however, basic interpretation procedures are straightforward. Like any geologic mapping campaign, interpretation usually starts with a phase of reconnaissance. Because the distance between seismic lines is so close (e.g., $12.5 \mathrm{~m}$ or $25 \mathrm{~m}$ ), the data can be viewed as a contiguous earth cube. By panning through tens, hundreds, and thousands of seismic lines over a matter of seconds and minutes, the subsurface can be animated, and the geology "comes alive." Panning through multiple, closely spaced seismic sections represents the equivalent of viewing an outcrop in a quarry wherein layer upon layer of vertical or horizontal sections are stripped away; the observer witnesses the changes in geology in three-dimensional space. This panning process involves digital manipulation and therefore can be done at any orientation, from vertical to horizontal, and any angle in between. This is informally referred to as "slicing and dicing," and provides unique insights into the stratigraphic and structural architecture of Earth's upper crust.

Thousands of square kilometers of data can be examined quickly, and key features or areas of interest are readily identified. Within these areas, reflections on individual seismic lines are then traced (so-called "picking"). These 
reflections are low-resolution proxies for individual bedding planes (Vail et al., 1977). Most interpretation software allows the investigator to interpret a small part (spatially) of a specific reflection (these would be called "seeds") and then instruct the computer to automatically pick the remaining area (so-called "autopicking"). A reflection that covers thousands of square kilometers can be autopicked in as little as a few minutes. Small, complex geologic features with random noise or seismic reflections that are dim or discontinuous represent a greater challenge. They require significant numbers of lines to be examined and more laboriously picked. Because each location within the generated grid (e.g., with an $\mathrm{X}$ and $\mathrm{Y}$ value) has a unique characteristic (e.g., two-way travel time [Z], horizon dip, seismic amplitude), once the reflection has been picked, the interpreter, again employing specialist software, can quickly calculate what are collectively referred to as "seismic attributes" (Figs. 1 and 2) (see Brown, 1999). The success of subsequent interpretations depends upon an interpreter's ability to visualize in three dimensions, recognize geologically significant patterns, and integrate a broad range of geologic disciplines including stratigraphy, geomorphology, structural geology, diagenesis, and magmatism.

\section{DEPOSITIONAL SYSTEMS ANALYSIS}

The original seismic stratigraphic methodologies outlined in Payton (1977) were developed on two-dimensional seismic cross sections of sedimentary basin fills. No imaging of the planform of the depositional systems and how they stacked was available. Low resolution seismic facies maps, based on qualitative descriptions of seismic reflection amplitude and continuity, as well as reflection architecture (e.g., oblique, sigmoid) and reflection terminations (e.g., toplap, downlap), captured planview distributions of depositional elements. With the advent of three-dimensional seismic data, the analysis of buried landforms became possible; seismic geomorphology (Posamentier, 2000) was the logical next step in the seismic analysis of depositional systems. Threedimensional seismic data, particularly the first second of data (typically the upper 800-1000 m of geology) where the resolution is best, are well suited not only for the static analyses of landscapes and seascapes, in other words the study of "snapshots" of Earth's surface at a moment in time, but also for the dynamic analyses of these landforms (i.e., how they evolve through time) (e.g., Posamentier, 2001). For example, successive horizontal slices through deposits of a deepwater
A)

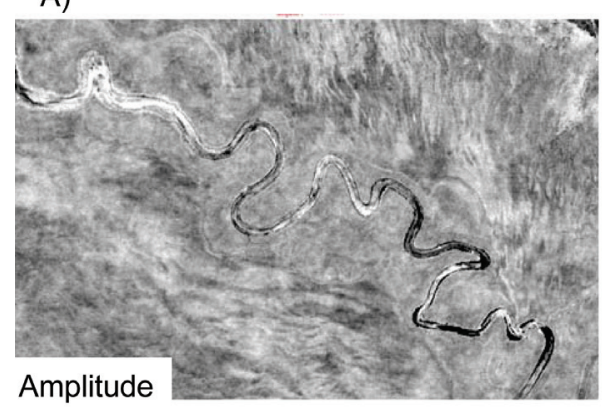

five $\mathrm{km}$

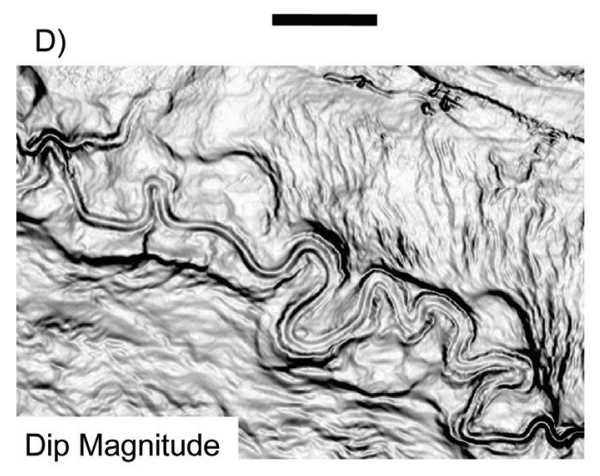

B)

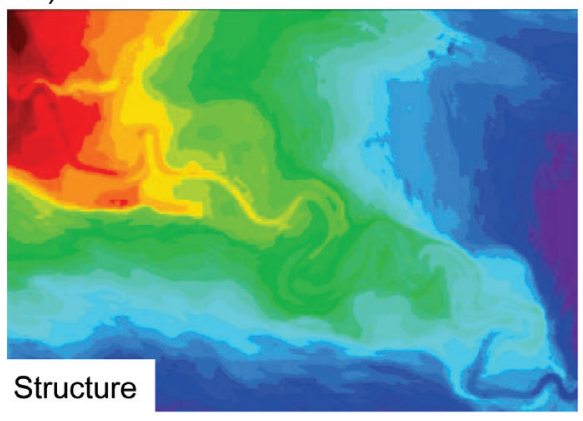

E)

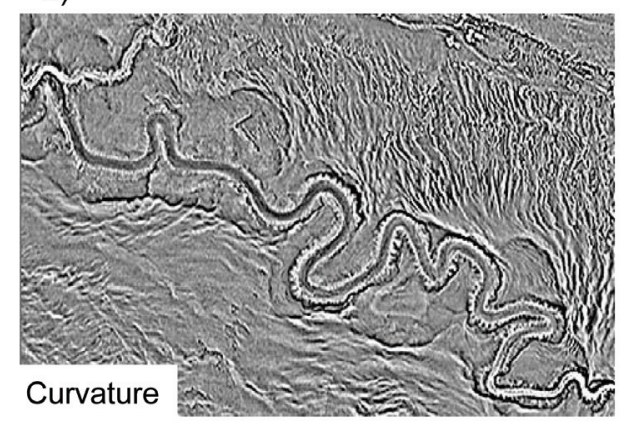

C)

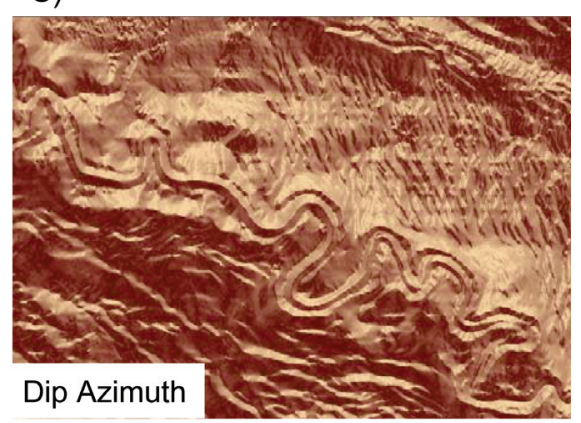

F)

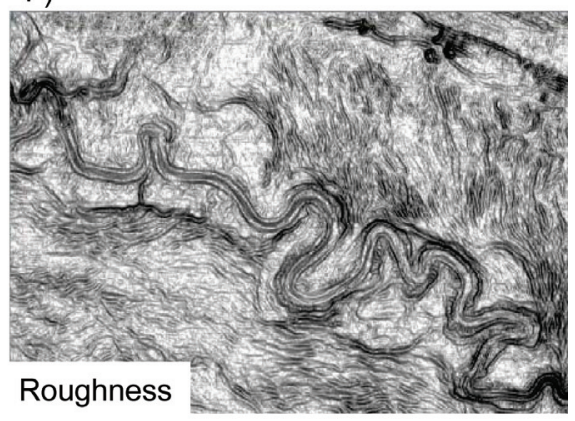

Figure 1. Deepwater Pleistocene channel, DeSoto Canyon area, Gulf of Mexico. (A) Reflection amplitude map showing amplitude strength of the upper bounding surface of the channel and surrounding area. The channel thalweg stands out because it is sand filled and therefore has a higher acoustic impedance than the mud dominated overbank environment. Dark gray—high seismic amplitude; light gray-low seismic amplitude. (B) Time structure map - the channel belt stands structurally higher than the flanking overbank area in response to aggradation of the levees and associated channel belt fill above the basin plain. Red—structurally high; blue—structurally low. (C) Dip azimuth map (combination of dip and azimuth attributes). The channel thalweg appears to stand higher than the channel belt of which it is a part because of differential compaction of the sand-filled channel contrasted with the more mud-prone overbank. Note also the sediment waves present in the overbank areas flanking the channel belt. (D) Dip magnitude map-the channel belt is more apparent in this depiction. It is elevated relative to the flanking overbank because of differential compaction and consequently represents an inversion of topography. Dark gray-high dip; light gray-low dip. (E) Curvature map. This map highlights local variations in curvature (a measure of the magnitude of deviation from a straight line) and brings to light such subtle features as the small slump scars located on the inner levees adjacent to the channel thalweg. (F) Roughness map. Roughness variations across the area highlight the channel thalweg as well as the sediment waves in the overbank area. After Posamentier (2005). 


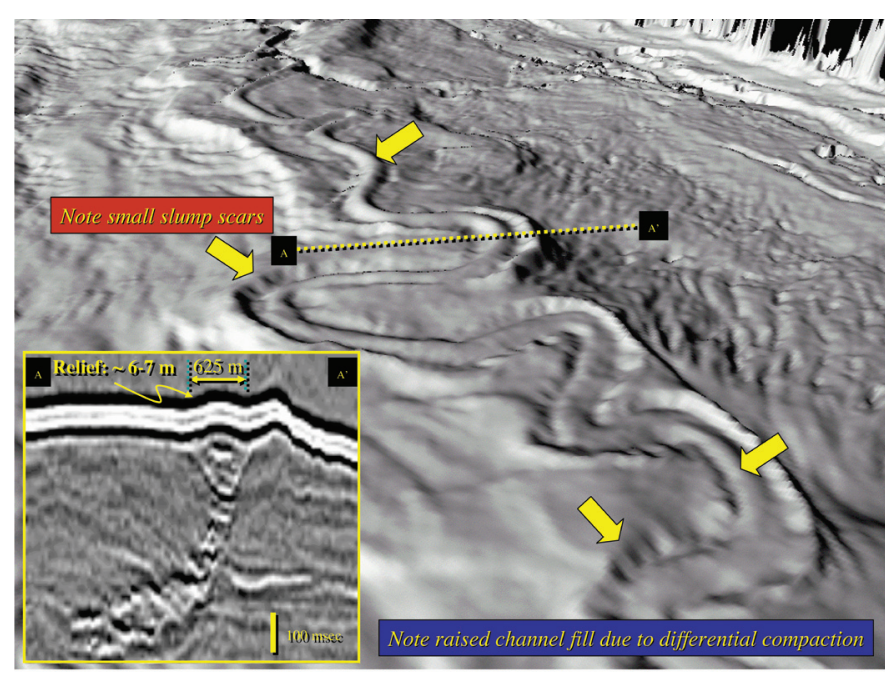

Figure 2. Illuminated and perspective view of the surface shown in Figure 1. The elevated aspect of the channel thalweg with its associated levees becomes quite apparent. The inset depicts a cross section through the channel showing that the thalweg is associated with high reflection amplitude, indicative of a higher acoustic impedance relative to the surrounding mud and therefore suggesting the presence of sand. After Posamentier (2003) and Posamentier (2004).

channel-overbank system illustrate the origin and progressive evolution of a crevasse splay from initially poorly organized sediment waves to better organized distributive channels (Fig. 3). Again, this sheds light on processes sedimentologically relevant to the development of deepwater deposition.

As exemplified above, a depositional setting that has benefited particularly from the study of three-dimensional seismic data is the deepwater environment. Deepwater deposits were not well understood in the past for a variety of reasons, including (1) their largely inaccessible location, which made study of these deposits at their deposition sites difficult; (2) the fact that most deepwater settings are not currently areas of active sedimentation; and (3) the fact that even those systems that are active are difficult to study because of the high energy involved in the deepwater sedimentation process. However, over the past 10 years, reservoirs on continental
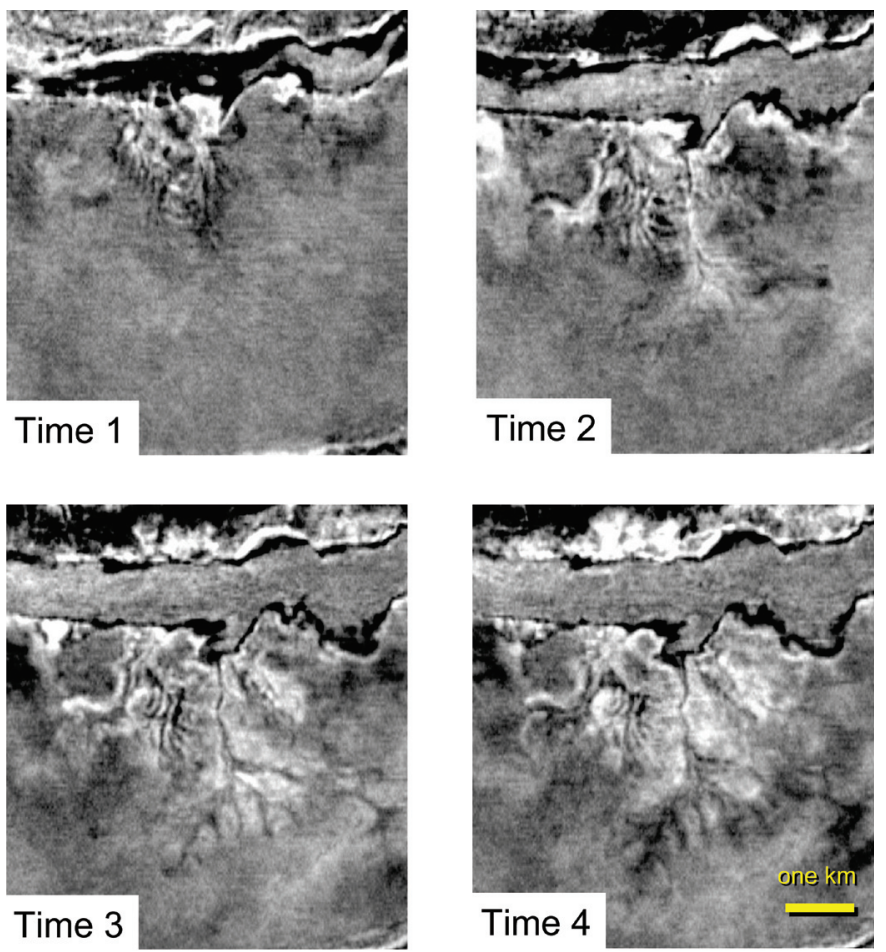

Figure 3. Four time slices through a crevasse splay associated with a PlioPleistocene channel in the deep water of the eastern Gulf of Mexico. The splay at Time 1 is disorganized and characterized by subtle transversely oriented sediment waves. Gradually, over Times 2-4, the splay becomes more organized until it is characterized by a well-developed distributive network.

slopes and in deep basinal settings have become increasingly important targets for worldwide exploration as a result of improvements in deepwater drilling technology (e.g., Pettingill, 2001). The infusion of three-dimensional data has literally added a new dimension to the investigation of these deposits (Posamentier and Kolla, 2003). In Figure 4A, for example, a sinuous deepwater channel is shown using a display of the dip azimuth on a reflection marking the top of the channel (Posamentier et al., 2000). The process of thalweg migration within the channel can be recognized using a hori-

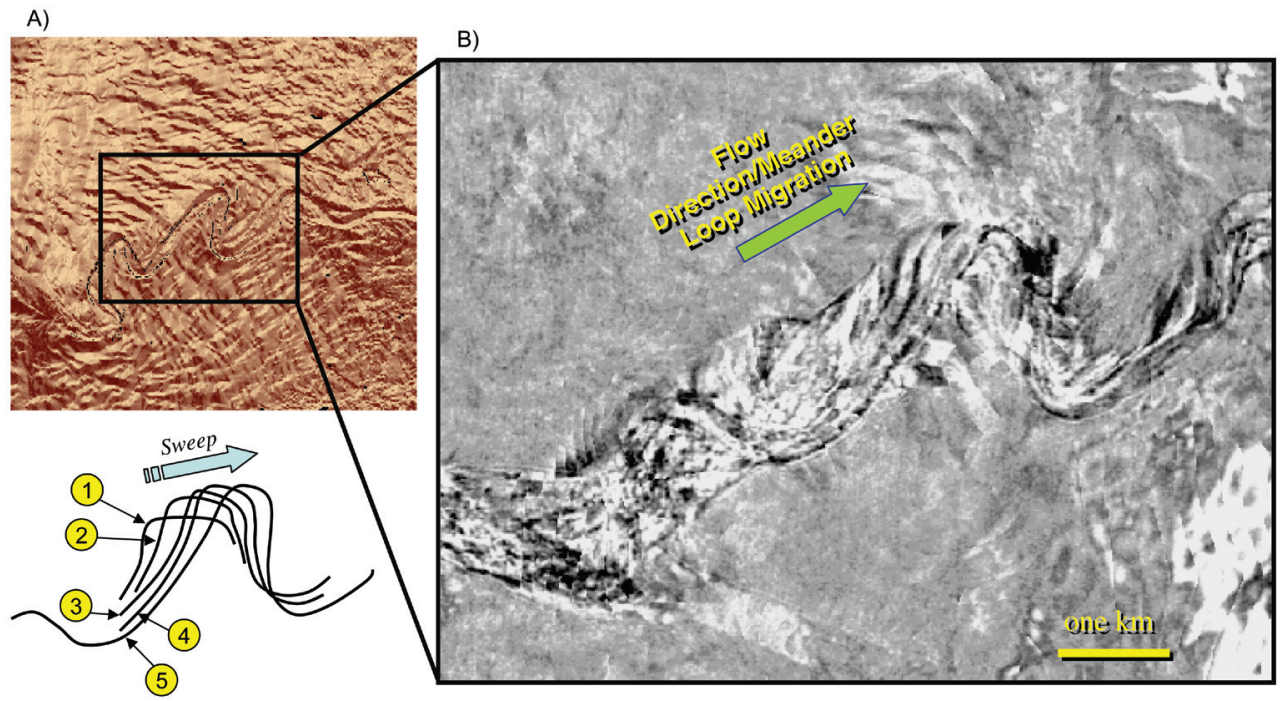

Figure 4. (A) Dip azimuth map on the upper bounding surface of a Pleistocene leveed channel on the deep basin floor in the Makassar Strait, offshore Kalimantan, Indonesia (from Posamentier et al., 2000). Note the extensive sediment waves (corduroy pattern) on either side of the channel. (B) Time slice through this channel illustrating shifted thalweg position through time. Meander loops are observed to migrate in the down-flow direction. 

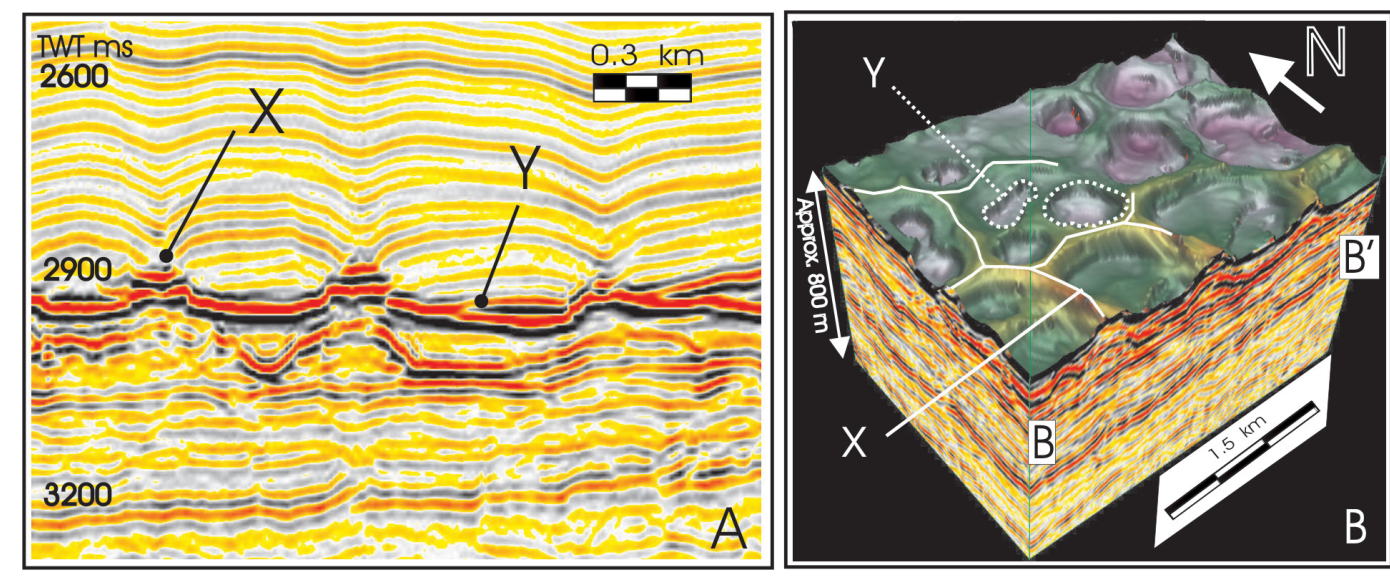

Figure 5. Seismic line and seismic cube revealing an opal A to opal CT boundary from the Faeroe-Shetland Basin, UK. (A) Seismic line B-B' taken from one of the two sides of the seismic cube (B) that face the reader. This seismic line shows that the front developed a series of ridges (marked $X$ ) and troughs (marked Y). The opal A-opal CT conversion occurred earlier in the areas that became ridges, leading to compaction and the generation of trough-like depressions. The images show that diagenetic fronts may develop nonplanar forms and cause large-scale deformation in sedimentary basins. After Davies (2005). (B) Seismic cube, one face of which intersects the seismic line in A. The front is buried at a depth of 500-700 m, but the overburden has been stripped away (a process known as "sculpting") to reveal the planform and relief of the opal A to opal CT diagenetic front. It shows that the ridges have a polygonal planform geometry. Green—high; purple-low.

zontal slice through a seismic volume (a so-called "time-slice"; see Fig. 4B). Figure 2 shows the presence of slumps on the inner walls of the channel-levee systems, a process that could have an important effect on reservoir properties through the generation of impediments to subsurface fluid flow. These types of images and their analysis provide important glimpses into the nature and evolution of generally inaccessible deepwater systems.

\section{DIAGENETIC PROCESSES}

It is not surprising that sedimentary bodies that are tens to hundreds of meters thick and many square kilometers in lateral extent can be studied usefully using three-dimensional seismic reflection profiling. Perhaps less expected is the role that this type of geophysical data could have in the study of diagenetic processes, particularly thermochemical reactions, as one could easily assume that the effects of diagenetic processes are discernable only at pore-scale. Some diagenetic reactions, such as the change from biogenic silica (opal A) to a crystalline form (opal CT), can lead to changes in the porosity and cementation of sediment and therefore have an associated change in acoustic impedance, which means that they can be imaged seismically (Hein et al., 1978). "Seismodiagenetic" analysis breaks the fundamental seismic stratigraphic rule originally outlined in Payton (1977), because diagenetic reflections are not necessarily time lines. We therefore consider the use of seismic data to understand diagenetic processes to be an exciting, new subdiscipline of seismic stratigraphy.

Like other geologic processes discussed here, the actual processes cannot be witnessed, but the morphology of the fronts can be mapped over areas of $10^{2}-10^{4} \mathrm{~km}^{2}$ of sedimentary basins. This represents a completely different perspective from most conventional diagenetic studies carried out at bed- or pore-scale or limited by two-dimensional seismic data. The three-dimensional shape of opal A to opal CT fronts is starting to yield important clues as to how diagenetic fronts advance through sediments undergoing burial, as well as the controls on this process. In the example shown here (Fig. 5), an industry borehole (214/4-1) has calibrated the seismic data confirming that a bright continuous reflection that cross-cuts stratigraphy is an opal A to opal CT diagenetic front that has developed a polygonal ridgedepression form (Fig. 5A). Because the host sediments are located above a polygonal fault set, they have a preexisting deformational relief that has been adopted by the diagenetic front. Therefore, a starting pattern of polygonal ridges existed at an early stage of front advancement. For reasons that remain uncertain, the diagenetic conversion occurred at the polygonal ridges prior to adjacent sediments, and because it causes porosity loss (Tada, 1991), compaction and overburden subsidence occurred in these areas. This is a new type of differential compaction mechanism that can cause large-scale deformation in sedimentary basins (Davies, 2005). Furthermore, the development of the differential front morphology in itself provides clues as to what processes are potentially involved in front advancement, such as fracturing and mass transport of silica. With the evaluation of additional data and improved geophysical resolution, perhaps other types of diagenetic conversion may be imaged in years to come. Will it be the illite-smectite transition or dolomitization?

\section{MAGMA INTRUSION IN THE UPPER CRUST}

The study of igneous intrusions has a research history spanning nearly 200 years. In outcrop, only partial exposure of exhumed sills is common, limiting the totality and consequently the accuracy of the mapping that can be carried out. Insights into how sills propagate and link with each other are therefore limited and rely largely on mechanical models. Two-dimensional seismic data commonly have imaged igneous intrusions and magma bodies (e.g., Joppen and White, 1990; Makovsky and Klemperer, 1999), but the lack of three-dimensional coverage does not allow for evaluation of intrusion processes. Because volcanic continental margins 
are important hydrocarbon provinces, extrusive and intrusive rocks can be imaged using three-dimensional seismic data (Davies et al., 2002; Hansen et al., 2004, Trude, 2004). The true three-dimensional form of dikes and sills can easily be ascertained because igneous rocks have high acoustic contrasts relative to the host sedimentary strata. Sill geometries and seismic attributes such as the amplitude and dip of a reflection from the top of a sill can reveal features that are diagnostic indicators of flow directions (e.g., Thomson and Hutton, 2004). Figure 6 shows a series of finger-like protuberances that are interpreted on the basis of industry borehole calibration in the basin to be part of a dolerite sill that has been intruded into Tertiary-aged siltstones and claystones. Because the sill has much higher seismic amplitudes than the surrounding country rock, processing software uses a technique termed "opacity rendering" to render the country rock transparent, revealing the form of the sill. The interpretation of this data set suggests that primary and secondary magma tubes feed secondary and tertiary flow units (Thomson and Hutton, 2004). Although flow direction criteria can be found in outcrops of sills, this example shows that seismic imaging can have an important future role to play in the study of magma intrusion in the upper crust. Such intrusions are of interest to the petroleum geologist because they cause contact metamorphism within adjacent sediments and may result in the expulsion of fluids. Both processes are likely to degrade associated reservoir quality.

\section{FLUID FLOW IN SEDIMENTARY BASINS}

Fluid transport pathways can be detected on some threedimensional seismic data, at least at a macro scale, because the fluids can change the acoustic properties of the host sediments. Indeed, this geophysical response has historically been a major clue in the hunt for hydrocarbons, as geophysicists

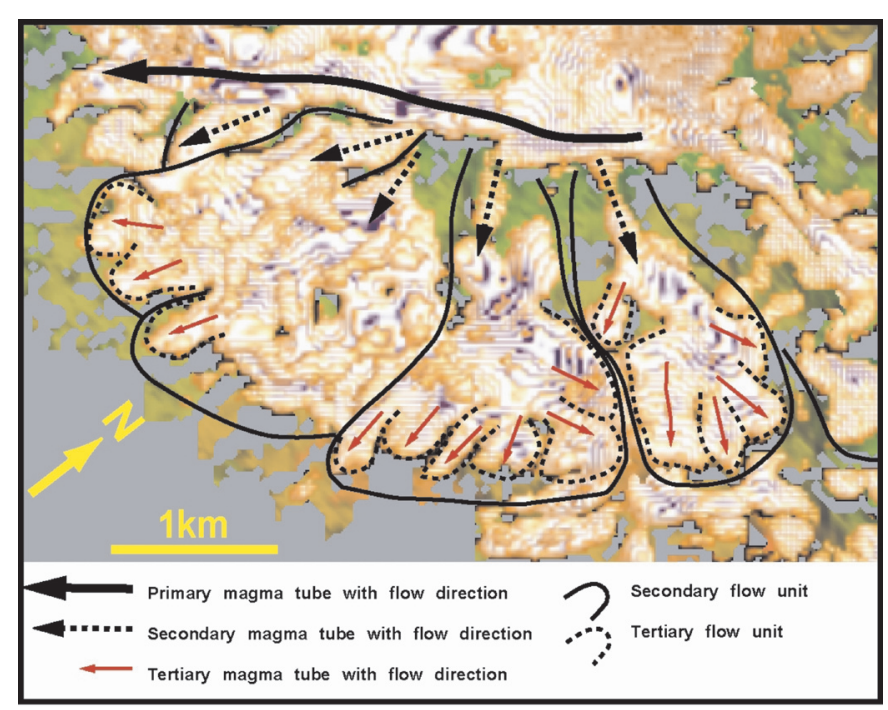

Figure 6. Plan view of a dolerite sill in which the low amplitude country rock has been made transparent (using an "opacity" technique). The fingers represent magma tubes that have hierarchical organization. Secondary magma tubes are fed from a primary magma tube. These feed secondary flow units that in turn feed the finger-like tertiary flows (after Thomson and Hutton, 2004). have been able to use seismic "bright spots" on two-dimensional seismic data as hydrocarbon indicators (Allen and Peddy, 1993). Understanding fluid flow pathways is another theme that is critical for hydrocarbon exploration and production and has received much attention. Potential fluid flow pathways can be determined by several indirect means using three-dimensional seismic data, including the use of specialist processing. For example, the red coloration in a seismic line from a three-dimensional volume in the North Sea, UK (Fig. 7 ), indicates the probability of vertical discontinuities representing gas migration pathways, also known as chimneys. The fault on the left of the seismic line shows evidence of being an active gas migration pathway, whereas faults in the center of the line show no evidence of gas migration. The processing software highlights vertical disturbances in the seismic data and assesses the likelihood that they are related to fluid migration pathways. It is critical for hydrocarbon exploration to understand which potential hydrocarbon conduits are active and which are not. From an academic standpoint, this type of analysis has great value in that it can be used to show how sedimentary basins de-gas and how fluids and fluid-sediment mixes enter the atmosphere or hydrosphere. Again, seismic data is not a panacea in this regard, but a tool that can be used in conjunction with other techniques.

\section{OTHER RESEARCH AVENUES}

There are a plethora of additional avenues of research, which we have not the space to address, to which threedimensional seismic reflection data sets have made great contributions (Cartwright and Huuse, 2005). Structural geology has benefited just as significantly as the disciplines discussed above. It is not surprising, therefore, that three-dimensional seismic data have allowed extensive study of how faults grow and link, for example (Mansfield and Cartwright, 2001; Walsh et al., 2003). It has also led to the discovery of a new type of fault system, polygonal faults, which were first recognized in three-dimensional seismic data sets from the Tertiary of

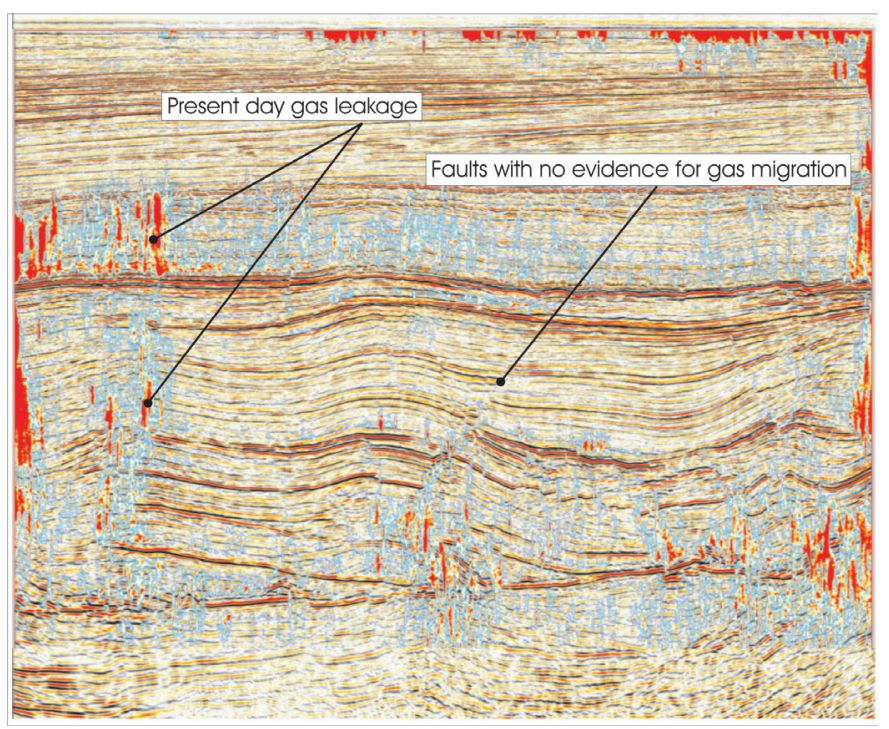

Figure 7. Image of gas migration pathways on seismic data from the North Sea, UK. Red marks gas migration pathways along faults. 
the North Sea (Cartwright, 1994) and now have been recognized in many other basins worldwide (Cartwright and Dewhurst, 1998). Subsurface imaging of meteorite impact craters using three-dimensional reflection data offers new avenues for bolide impact research (Stewart and Allen, 2002) beyond the results derived from two-dimensional experiments (Morgan and Warner, 1999). For research into soft sediment deformation, numerous km-scale sediment intrusions have been revealed within the Paleogene of the North Sea, UK (e.g., Huuse et al., 2004). The subsurface plumbing of giant volcanoes is also now being elucidated (Davies and Stewart, 2005). Three-dimensional seismic reflection data have also been used to examine and further refine our understanding of plate boundaries (Davies et al., 2005). This list of opportunities will no doubt continue to grow in the next decade, particularly given the recent academic funding in the United States for a three-dimensional seismic acquisition vessel.

\section{CONCLUSIONS}

Three-dimensional seismic reflection profiling has emerged as a fundamental tool in sedimentary basin analysis. Although the processes cannot be witnessed, their products can have diagnostic geophysical attributes and threedimensional geometry that provide important clues. The diversity of earth science disciplines benefiting from these data is increasing; however, the costs of such data remain quite prohibitive for academic research. Consequently, because most of these data are acquired by the hydrocarbon industry, academic studies will rely largely on collaboration with this industry. We are truly at the start of the scientific journey; the advances made thus far are dwarfed by future potential.

\section{ACKNOWLEDGMENTS}

H.W.P. thanks Anadarko Canada Corporation for permission to publish this paper. R.J.D. thanks Joe Cartwright and the Ph.D. research students in the 3DLab at Cardiff University for discussion. Paul de Groot of the dGB group and Mærsk Olie of Gas AS are thanked for providing the seismic line in Figure 7. PGS Exploration Ltd. and Veritas DGC Ltd. are sincerely thanked for permission to use seismic data in this paper and in others published by the authors. We thank reviewers Carlos Pirmez, Bruce Hart, Mike Enachescu, and Don White. Lastly, we are grateful to Gerry Ross for his editorial assistance.

\section{REFERENCES CITED}

Allen, J.L., and Peddy, C.P., 1993, Amplitude variation with offset: Gulf Coast case studies: Tulsa, Oklahoma, Society of Exploration Geophysicists, $126 \mathrm{p}$.

Bally, A.W., 1987, Atlas of seismic stratigraphy: Tulsa, Oklahoma, American Association of Petroleum Geologists, Studies in Geology no. 27, 125 p.

Brown, A.R., 1999, Interpretation of three-dimensional seismic data: American Association of Petroleum Geologists Memoir 42, 5th Edition, $510 \mathrm{p}$.

Cartwright, J.A., 1994, Episodic basin-wide fluid expulsion from geopressured shale sequences in the North Sea Basin: Geology, v. 22, p. 447-450, doi: 10.1130/00917613(1994)022<0447:EBWFEF>2.3.CO;2.

Cartwright, J.A., and Dewhurst, D., 1998, Layer-bound compaction faults in fine-grained sediments: Geological Society of America Bulletin, v. 110, p. 1242-1257, doi: 10.1130/0016-7606(1998)1 10<1242:LBCFIF > 2.3.CO;2.

Cartwright, J.A., and Huuse, M.R., 2005, 3D seismic technology: The geological "Hubble": Basin Research, v. 17, p. 1-20, doi: 10.1111/j.1365-2117.2005.00252.x.

Davies, R.J., 2005, Differential compaction and subsidence in sedimentary basins due to silica diagenesis: A case study: Geological Society of America Bulletin, v. 117, p. 1146-1155.

Davies, R.J., and Stewart, S.A., 2005, Emplacement of giant mud volcanoes in the South Caspian Basin: 3D seismic reflection imaging of their root zones: Journal of the Geological Society, v. 162, p. 1-4, doi: 10.1144/0016764904-082.

Davies, R.J., Bell, B., Cartwright, J.A., and Shoulders, S., 2002, Three-dimensional seismic imaging of dike-fed submarine volcanoes: Geology, v. 30, p. 223-226, doi: 10.1130/G21530.1.

Davies, R.J., Cartwright, J.A., Stewart, S.A., Lappin, M., and Underhill, J.R., 2004, 3D seismic technology: Application to the exploration of sedimentary basins: London, Geological Society Memoir 29, $355 \mathrm{p}$.

Davies, R.J., MacLeod, C.J., Morgan, R., and Briggs, S.E., 2005, Termination of a fossil continent-ocean fracture zone imaged with three-dimensional seismic data: The Chain Fracture Zone, eastern Equatorial Atlantic: Geology, v. 33, p. 641-644, doi:10.1130/G21530.1.

Grand, S.P., van der Hilst, R.D., and Widiyantoro, S., 1997, Global seismic tomography: A snapshot of convection in the Earth: GSA Today, v. 7, no. 4, p. 1-7.

Hansen, D.M., Cartwright, J.A., and Thomas, D., 2004 , 3D seismic analysis of the geometry of igneous sills and sill junction relationships, in Davies, R.J., et al., eds., 3D seismic technology: Application to the exploration of sedimentary basins: London, Geological Society Memoir 29, p. 199-208.

Hein, J.R., Scholl, D.W., Barron, J.A., Jones, M.G., and Miller, J., 1978, Diagenesis of late Cenozoic diatomaceous deposits and formation of the bottom-simulating reflector in the southern Bering Sea: Sedimentology, v. 25, p. 155-181.

Huuse, M., Duranti, D., Steinsland, N., Guargena, C.G. Prat, P., Holm, K., Cartwright, J.A., and Hurst, A., 2004, Seismic characteristics of large-scale sandstone intrusions in the Paleogene of the South Viking Graben, UK, and Norwegian North Sea, in Davies, R.J., et al., eds., 3D seismic technology: Application to the exploration of sedimentary basins: London, Geological Society Memoir 29, p. $262-277$.

Joppen, M., and White, R.S., 1990, The structure and subsidence of the Rockall Trough from two ship seismic experiments: Journal of Geophysical Research, v. 95, p. 19,821-19,837.

Makovsky, Y., and Klemperer, S.L., 1999, Measuring the seismic properties of Tibetan bright spots: Evidence for free aqueous fluids in the Tibetan middle crust: Journal of Geophysical Research, v. 104, p. 10,795-10,825.

Mansfield, C., and Cartwright, J.A., 2001, Fault growth by linkage: Observations and implications from analogue models: Journal of Structural Geology, v. 23, p. 745-763, doi: 10.1016/S0191-8141(00)00134-6.

Morgan, J., and Warner, M., 1999, Chicxulub: The third dimension of a multi-ring impact basin: Geology, v. 27, p. 407-410, doi: 10.1130/0091-7613(1999)027<0407: CTTDOA $>2.3 . \mathrm{CO} ; 2$
Payton, X., 1977, Seismic stratigraphy—applications to the exploration of sedimentary basins: American Association of Petroleum Geologists Memoir 26, 516 p.

Pettingill, H.S., 2001, Giant field discoveries of the 1990s: The Leading Edge, v. 20, p. 698-704, doi: 10.1190/1.1487280.

Posamentier, H.W., 2000, Seismic stratigraphy into the next millennium; a focus on three-dimensional seismic data: American Association of Petroleum Geologists Annual Conference, New Orleans, Louisiana, 16-19 April, p. A118. Posamentier, H.W., 2001, Lowstand alluvial bypass systems: incised vs. unincised: AAPG Bulletin, v. 85, p. 1971-1993. Posamentier, H.W., 2003, Depositional elements associated with a basin floor channel-levee system: Case study from the Gulf of Mexico: Marine and Petroleum Geology, v. 20, p. 677-690, doi: 10.1016/j.marpetgeo.2003.01.002.

Posamentier, H.W., 2004, Seismic geomorphology: imaging elements of depositional systems from shelf to deep basin using 3D seismic data: Implications for exploration and production, in Davies, R.J., et al., eds., 3D seismic technology: Application to the exploration of sedimentary basins: London, Geological Society Memoir 29, p. 11-24.

Posamentier, H.W., 2005, Application of 3D seismic visualization techniques for seismic stratigraphy, seismic geomorphology, and depositional systems analysis: Examples from fluvial to deep-marine depositional environments, in Doré A.G., and Vining, B., eds., Petroleum geology of northwest Europe and global perspectives: Proceedings of the 6th Petroleum Geology Conference, p. 1565-1576.

Posamentier, H.W., and Kolla, V., 2003, Seismic geomorphology and stratigraphy of depositional elements in deepwater settings: Journal of Sedimentary Research, v. 73, p. 367-388.

Posamentier, H.W., Meizarwin, X., Wisman, P.S., and Plawman, T., 2000, Deepwater depositional systems-ultradeep Makassar Strait, Indonesia, in Weimer, P., et al., eds. Deep water reservoirs of the world: Gulf Coast Section, Society for Sedimentary Geology (SEPM) Foundation, 20th Annual Research Conference: Houston, Society for Sedimentary Geology (SEPM) Foundation, p. 806-816.

Stewart, S.A., and Allen, P.J., 2002, A 20-km-diameter multiringed impact structure in the North Sea: Nature, v. 418, p. 520-523, doi: 10.1038/nature00914.

Tada, R., 1991, Compaction and cementation in siliceous rocks and their possible effect on bedding enhancement, in Einsele, G., et al., eds., Cycles and events in stratigraphy: Berlin, Springer-Verlag, p. 481-491.

Thomson, K., and Hutton, D., 2004, Geometry and growth of sill complexes: Insights using three-dimensional seismic from the North Rockall Trough: Bulletin of Volcanology v. 66 , p. 364-375, doi: 10.1007/s00445-003-0320-z.

Trude, K.J., 2004, Kinematic indicators for shallow level igneous intrusions from 3D seismic data: Evidence of flow direction and feeder location, in Davies, R.J., et al., eds., 3D Seismic Technology: Application to the Exploration of Sedimentary Basins: London, Geological Society Memoir, p. 209-217.

Vail, P.R., Mitchum, R.M., Jr., and Thompson, S., III, 1977, Seismic stratigraphy and global changes of sea level, part 3 : Relative changes of sea level from coastal onlap, in Payton, C.E., ed., Seismic stratigraphy—Applications to hydrocarbon exploration: American Association of Petroleum Geologists Memoir 26, p. 63-81.

Walsh, J.J., Bailey, W.R., Childs, N.A., and Bonson, C.G. 2003, Formation of segmented normal faults: A 3-D perspective: Journal of Structural Geology, v. 25, p. 1251-1262, doi: 10.1016/S0191-8141(02)00161-X.

Weimer, P., and Davis, T.L., 1996, Applications of 3-D seismic data to exploration and production: Tulsa, Oklahoma, American Association of Petroleum Geologists Studies in Geology, v. 42, 270 p.

Yilmaz, O., 2001, Seismic data analysis and processing, inversion, and interpretation of seismic data: Tulsa, Oklahoma, Society of Exploration Geophysicists, 2027 p.

Manuscript received 29 March 2005; accepted 2 August 2005. 